\title{
The Reaction between Diazoalkanes and Allylic Halides Carrying Electronegative $\gamma$-Substituents. 4. Conformational Equilibria of Highly Substituted 1-Pyrazolines
}

\author{
TRYGVE GULBRANDSEN ${ }^{\mathrm{a}}$ and PER KOLSAKER ${ }^{\mathrm{b}}$
}

a Nyegaard \& Co A/S, Nycoveien 2, Oslo 4, Norway and ${ }^{\mathrm{b}}$ Department of Chemistry, University of Oslo, Box 1033, Blindern, Oslo 3, Norway

Some di- and trisubstituted 1-pyrazoline-3-carbonitriles were synthesized and the coupling constants between vicinal protons were measured. In those cases where only one large substituent is present, the pseudoequatorial position is preferred. When two large groups are present trans to each other in vicinal position, the dipseudoaxial conformation is preferred. The compounds with preference for the dipseudoaxial conformation unexpectedly gave only cyclopropane derivatives when decomposed.

In our studies of the thermal decomposition of 1-pyrazolines substituted with cyano- or ester groups in the 3-position, 1,3-dipolar cycloaddition reactions of diazoalkanes and $\alpha, \beta$-unsaturated diesters and dinitriles led to formation of 1-pyrazolines with the same stereochemical relation between the 4- and 5-substituents. ${ }^{1-3}$ On the basis of the coupling constants between the vicinal hydrogens, and the sterical restrictions of 1,3-dipolar cyloaddition, ${ }^{4}$ the substituents were assumed to be trans to each other (Scheme 1).

The trans structure of $3 d$ was verified by X-ray diffraction methods. ${ }^{5}$ In the cases where $R^{3} \neq X$, the stereochemistry of the starting alkene was assumed to be preserved in the 1-pyrazoline, based on the concertedness of the 1,3-dipolar cycloaddition reactions. ${ }^{4}$

As pointed out earlier, ${ }^{6-7}$ the 1-pyrazoline ring system equilibrates in solution between the two conformations with $C_{\mathrm{s}}$ symmetry, where pseudoaxial and -equatorial positions are rapidly interchanging (Scheme 2). In analogy with cyclo-
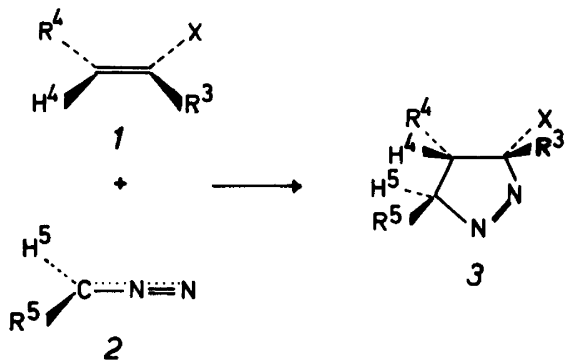

3

Scheme 1. 1a, $X=R^{3}=C N, R^{4}=C B r M e_{2} ; 1 b$, $\mathrm{X}=\mathrm{R}^{3}=\mathrm{CN}, \quad \mathrm{R}^{4}=\mathrm{Bu}^{\mathrm{t}} ; 1 c, \mathrm{X}=\mathrm{CN}, \mathrm{R}^{3}=\mathrm{Me}$, $\mathrm{R}^{4}=\mathrm{CBrMe}_{2} ; \quad 1 d, \quad \mathrm{X}=\mathrm{CN}, \quad \mathrm{R}^{3}=\mathrm{Bu}^{\mathrm{t}}$, $\mathrm{R}^{4}=\mathrm{CBrMe}_{2} ; 1 e, \mathrm{X}=\mathrm{R}^{3}=\mathrm{CO}_{2} \mathrm{Me}, \mathrm{R}^{4}=\mathrm{CBrMe}_{2}$; $2 a, \mathrm{R}^{5}=\mathrm{H} ; 2 b, \mathrm{R}^{5}=\mathrm{Me} ; 2 c, \mathrm{R}^{5}=\mathrm{Ph} ; 2 d, \mathrm{R}^{5}=\mathrm{Bu}^{\mathrm{t}}$; 3 , see Table 1 .

hexane systems, the relative population of each conformation is controlled by sterical interactions between substituents, and it is generally accepted that the conformer with the highest number in pseudoequatorial positions will be the most
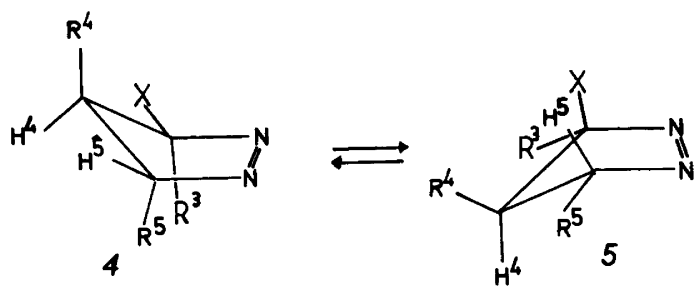

Scheme 2. 
stable. ${ }^{6}$ The observed vicinal coupling constants must, as a consequence of the dynamic situation, appear as the weighted average of the coupling constant for each conformer. Based on model substances, coupling constants of 1-pyrazolines have been used to calculate the conformational distribution in solution. ${ }^{8}$

The role of conformational equilibrium of 1-pyrazolines in determining the proportion between alkene and cyclopropane derivatives formed during decomposition is discussed in the literature. ${ }^{6-7} \mathrm{~A}$ general view is that alkenes are

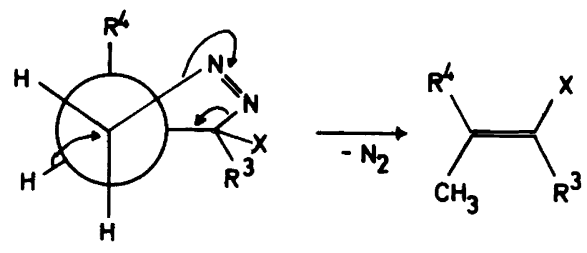

Scheme 3. formed via migration of a pseudoequatorial group (hydrogen or alkyl) from C 4 to replace the leaving nitrogen at C5 (Scheme 3).

Consequently, knowledge of the conformational situation for 1-pyrazoline derivatives is essential for prediction of the decomposition products, and for consideration of the mechanism of the pyrolysis reaction.

${ }^{1} \mathrm{H}$ NMR data of 1-pyrazolines prepared according to Scheme 1 are given in Table 1 .

The stereochemistry of the alkenes $1 c$ and $1 d$ (Scheme 1) deserves some comment. 1d was synthesized by the Wittig reaction between triphenylphosphonium isobutylide and 3,3dimethyl-2-oxobutyronitrile followed by allylic bromination with $N$-bromosuccinimide (NBS). ${ }^{1} \mathrm{H}$ NMR of the reaction mixture from the Wittig reaction showed that a stereochemically pure alkene was formed (doublet at $5.8 \mathrm{ppm}$ with splitting of $9.5 \mathrm{~Hz}$ ). From the nature of the Wittig reaction it is likely that formation of the least sterically hindered alkene is preferred ${ }^{11}$ and for that reason the product was assumed to have the

Table 1. Chemical shifts and vicinal coupling constants of ring protons in pyrazolines 3 .

\begin{tabular}{|c|c|c|c|c|c|c|c|c|c|c|c|c|}
\hline \multirow{2}{*}{$\begin{array}{l}\text { Com- } \\
\text { pound }\end{array}$} & \multirow[t]{2}{*}{$X$} & \multirow[t]{2}{*}{$\mathbf{R}^{3}$} & \multirow[t]{2}{*}{$\mathbf{R}^{4}$} & \multirow[t]{2}{*}{$\mathrm{R}^{5}$} & \multirow[t]{2}{*}{$\delta_{\mathrm{H}^{4}}$} & \multirow[t]{2}{*}{$\delta_{\mathrm{R}^{s}}$} & \multirow[t]{2}{*}{$\delta_{\mathrm{H}^{5}}$} & \multicolumn{2}{|c|}{$J_{\mathrm{H}_{4} \mathrm{H}_{5}} / \mathrm{Hz}$} & \multirow{2}{*}{$\begin{array}{l}\text { Sol- } \\
\text { vent }^{a}\end{array}$} & \multicolumn{2}{|c|}{ Temp.Ref } \\
\hline & & & & & & & & cis & trans & & ${ }^{\circ} \mathrm{C}$ & \\
\hline $3 a$ & $\mathrm{CN}$ & $\mathrm{CN}$ & $\mathrm{Bu}^{\mathrm{t}}$ & $\mathbf{H}$ & 2.53 & 5.41 & 4.47 & 7.8 & 11.5 & 1 & -130 & $b$ \\
\hline $3 a$ & $\mathrm{CN}$ & $\mathrm{CN}$ & $\mathrm{Bu}^{\mathrm{t}}$ & $\mathrm{H}$ & 2.51 & 5.18 & 4.67 & 8.3 & 10.7 & 1 & -50 & $b, 9$ \\
\hline $3 b$ & $\mathrm{Me}$ & $\mathrm{MeCO}$ & $\mathrm{Me}$ & $\mathrm{Ph}$ & 1.92 & - & 4.68 & - & 10.4 & 2 & 30 & $6 a$ \\
\hline $3 c$ & $\mathrm{CO}_{2} \mathrm{Me}$ & $\mathrm{CO}_{2} \mathrm{Me}$ & $\mathrm{Bu}^{\mathrm{t}}$ & $\mathrm{H}$ & - & 4.83 & 4.30 & 8.4 & 10.0 & 2 & 30 & 8 \\
\hline $3 d$ & $\mathrm{CO}_{2} \mathrm{Me}$ & $\mathrm{CO}_{2} \mathrm{Me}$ & $\mathrm{CBrMe}_{2}$ & $\mathrm{Ph}$ & 3.12 & - & 5.77 & - & 10.0 & 2 & 30 & 2,3 \\
\hline $3 e$ & $\mathrm{MeCO}$ & $\mathrm{Me}$ & $\mathrm{Me}$ & $\mathrm{Ph}$ & 1.60 & - & 4.90 & - & 9.8 & 2 & 30 & $6 a$ \\
\hline $3 f$ & $\mathrm{CN}$ & $\mathrm{CN}$ & $\mathrm{CBrMe}_{2}$ & $\mathrm{H}$ & 3.62 & 5.71 & 5.37 & 8.0 & 8.0 & 3 & -70 & 1 \\
\hline $3 g$ & $\mathrm{CN}$ & $\mathrm{CN}$ & $\mathrm{CBrMe}_{2}$ & $\mathbf{P h}$ & - & - & 6.23 & & 8.7 & 4 & -52 & 2 \\
\hline $3 h$ & $\mathrm{CN}$ & $\mathrm{CN}$ & $\mathrm{CHMe}_{2}$ & $\mathbf{H}$ & 2.36 & 5.25 & 4.43 & 7.3 & 8.7 & 2 & -60 & 10 \\
\hline $3 i$ & $\mathrm{CO}_{2} \mathrm{Me}$ & $\mathrm{CO}_{2} \mathrm{Me}$ & $\mathrm{Ph}$ & $\mathrm{Me}$ & 3.60 & - & 4.95 & - & 8.5 & 2 & 30 & $6 a$ \\
\hline $3 j$ & $\mathrm{CO}_{2} \mathrm{Me}$ & $\mathrm{CO}_{2} \mathrm{Me}$ & $\mathrm{CBrMe}_{2}$ & $\mathrm{Me}$ & 3.20 & - & 5.62 & - & 7.8 & 2 & 30 & $b$ \\
\hline $3 k$ & $\mathrm{CO}_{2} \mathrm{Me}$ & $\mathrm{CO}_{2} \mathrm{Me}$ & $\mathrm{Bu}$ & $\mathbf{H}$ & - & 4.89 & 4.21 & 8.3 & 7.8 & 2 & 30 & 8 \\
\hline $3 l$ & $\mathrm{CO}_{2} \mathrm{Me}$ & $\mathrm{CO}_{2} \mathrm{Me}$ & $\mathrm{Et}$ & $\mathrm{H}$ & - & 4.86 & 4.24 & 8.3 & 7.4 & 2 & 30 & 8 \\
\hline $3 m$ & $\mathrm{CN}$ & $\mathrm{CN}$ & $\mathrm{CBrMe}_{2}$ & $\mathrm{Me}$ & 3.16 & - & 5.43 & - & 6.7 & 3 & -60 & $b$ \\
\hline $3 n$ & $\mathrm{CO}_{2} \mathrm{Me}$ & $\mathrm{CO}_{2} \mathrm{Me}$ & $\mathrm{Me}$ & $\mathrm{H}$ & 2.82 & 4.82 & 4.27 & 8.0 & 6.2 & 2 & 30 & 8 \\
\hline $3 o$ & $\mathrm{CN}$ & $\mathrm{Me}^{2}$ & $\mathrm{CBrMe}_{2}$ & $\mathrm{Me}$ & 3.00 & - & 5.11 & - & 5.4 & 2 & 30 & $b$ \\
\hline $3 p$ & $\mathrm{CN}$ & $\mathrm{Bu}^{\mathrm{t}}$ & $\mathrm{CBrMe}_{2}$ & $\mathrm{Me}$ & - & - & 5.21 & - & 4.9 & 2 & 30 & $b$ \\
\hline $3 q$ & $\mathrm{CN}$ & $\mathrm{Bu}^{\mathrm{t}}$ & $\mathrm{CBrMe}_{2}$ & $\mathbf{H}$ & 2.70 & 5.28 & 4.76 & 9.3 & 4.1 & 2 & 30 & $b$ \\
\hline $3 r$ & $\mathrm{CN}$ & $\mathrm{CN}$ & $\mathrm{Bu}^{\mathrm{t}}$ & $\mathrm{Bu}^{\mathrm{t}}$ & 2.74 & - & 5.48 & - & 3.2 & 3 & -30 & $b$ \\
\hline $3 r$ & $\mathrm{CN}$ & $\mathrm{CN}$ & $\mathrm{Bu}^{\mathrm{t}}$ & $\mathrm{Bu}^{\mathrm{t}}$ & 2.83 & - & 5.54 & - & 3.1 & 3 & -60 & $b$ \\
\hline $3 r$ & $\mathrm{CN}$ & $\mathrm{CN}$ & $\mathrm{Bu}^{\mathrm{t}}$ & $\mathrm{Bu}^{\mathrm{t}}$ & 2.91 & - & 5.62 & - & 2.1 & 3 & -90 & $b$ \\
\hline $3 s$ & $\mathrm{CN}$ & $\mathrm{CN}$ & $\mathrm{CBrMe}_{2}$ & $\mathrm{Bu}^{\mathrm{t}}$ & 3.22 & - & 5.57 & - & 2.8 & 4 & -60 & $b$ \\
\hline
\end{tabular}

\footnotetext{
${ }^{a}$ Solvents: $1 . \mathrm{CHCl}_{2} \mathrm{~F}, 2 . \mathrm{CDCl}_{3}, 3$. acetone- $d_{6}, 4 \cdot \mathrm{CCl}_{3} \mathrm{~F} .{ }^{b}$ This paper.
} 
$Z$-configuration. The resonance line for the vinylic proton of $1 d$ was positioned at $6.30 \mathrm{ppm}$, which corresponds to introduction of a bromine atom in the allylic position with retention of the alkene stereochemistry. ${ }^{12}$ The nonbrominated analogue of $1 c$ was formed as a 1:1 mixture of $Z$ and $E$-isomers, which were separated by fractional distillation. The shifts of the vinylic protons were 5.83 and $6.05 \mathrm{ppm}$, respectively. Bromination of both isomers resulted in the same allyl bromide with its vinylic resonance line at 6.33 ppm, very close to that of $1 d$.

As mentioned above, observed vicinal coupling constants appear as weighted averages according to the conformational equilibria positions (Scheme 2). The torsion angles between cis substituents are $20-30^{\circ}$ in both conformers, ${ }^{5,8}$ and according to the Karplus equation, ${ }^{13}$ the cis coupling constant will be large independent of the conformational distribution. In contrast, torsion angles between trans hydrogens will change from about $85^{\circ}$ when situated in diequatorial positions (conformer 4 ), to about $145^{\circ}$ when situated in diaxial positions (conformer 5). ${ }^{5}$ As a consequence of the Karplus equation, the coupling constant between the trans hydrogens will be small when 4 is dominating, and large whenever conformer 5 is the most stable one. ${ }^{8}$ In Table 1 the compounds appear in order of decreasing trans coupling constants.

At this point one must consider that differences in the substitution pattern may affect the size of the coupling constants in a somewhat unpredictable way. ${ }^{13}$ However, these effects are small compared to the differences from the top to the bottom of Table 1 and a change above $1.5 \mathrm{~Hz}$ is likely to indicate a change in the conformational equilibrium.

The 4-alkylsubstituted diesters $3 n, 3 l, 3 k$ and $3 c$ show a steady increase in the trans coupling constant with increasing size of $R^{4}$ $(\mathrm{Me}<\mathrm{Et}<\mathrm{Bu}<t-\mathrm{Bu}){ }^{8}$ Hence, it is obvious that when other substituents are small, a large $R^{4}$ will prefer the pseudoequatorial position (conformer 5 ). This effect may be due to the repulsive interaction between the hydrogens of $R^{4}$ in axial position and the $\pi$-electrons of the azo group. The preference for conformer 5 is also seen for the compounds $3 a, 3 d, 3 f$ and $3 g$, where only one large substituent is present in the ring (the bromoisopropyl group is regarded as similar in size to a tertiary butyl group). In this connection it should be mentioned that while $3 c$ is reported to be "locked" in conformation 5 below $-15^{\circ} \mathrm{C}, 8$ conformer 4 of the corresponding dinitrile $(3 a)$ is still significant at $-50^{\circ} \mathrm{C}$, as seen by a further increase of $J_{\text {trans }}$ when decreasing the temperature to $-130^{\circ} \mathrm{C}$.

However, the situation changes completely when more than one large group are present. In going from $3 f$ to $3 m$ to $3 s$ the 3- and 4-substituents are kept constant, while the 5-substituent increases from hydrogen through methyl to tertbutyl. The result is a drastic reduction of the coupling constant $(8.0-6.7-2.8 \mathrm{~Hz})$, which implies a complete change in the conformational equilibrium. In $3 s$ the bromoisopropyl group and the tert-butyl group have a strict preference for the pseudoaxial position, which is in sharp contrast to earlier observations. ${ }^{6-8}$ The same situation is seen for compounds $3 q$ and $3 r$, i.e. whenever two large vicinal groups are present in trans positions. The slightly higher coupling constant of $3 p$ relative to $3 q$ may indicate that the interaction between two pseudoaxial substituents at $\mathrm{C} 3$ and $\mathrm{C5}\left(\mathrm{Me}, \mathrm{Bu}^{\mathrm{t}}\right)$ becomes significant, thus reducing the stability of conformer 4 .

In this connection it is interesting to note the temperature dependency in the ${ }^{1} \mathrm{H}$ NMR spectra of $3 r$. When the temperature is reduced from $-30^{\circ} \mathrm{C}$ to $-60^{\circ} \mathrm{C}$ and further to $-90^{\circ} \mathrm{C}$, the coupling constant drops from 3.2 to 3.1 to $2.1 \mathrm{~Hz}$. Since a reduction in temperature will favor the most stable conformer, this drop in coupling constants represent additional evidence for the two tert-butyl groups being in pseudoaxial positions (conformer 4).

Another interesting feature of the spectra of $3 r$ is the increased splitting of the lines from the tert-butyl groups, indicating hindered rotation about one of the $\mathrm{C}-\mathrm{CMe}_{3}$ bonds at low temperature (see Experimental). Model considerations indicate that this is due to an interaction between the tert-butyl group at $\mathrm{C} 5$ and the pseudoaxial cyano group at $\mathbf{C} 3$.

The thermal decomposition into mixtures of cyclopropanes and alkenes of the 1-pyrazoline3,3-dinitriles appearing in Table 1 is summarized in Table 2 (Scheme 4).

We have earlier suggested that the preference for alkene formation in nonpolar solvents is due to the lack of external stabilization of the developing charge at $\mathbf{C 5}$, and that sterical effects are important in this connection. Since we have 


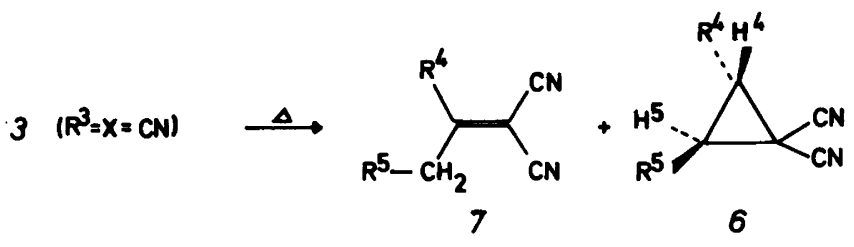

Scheme 4.

found that pyrazolines $3 r$ and $3 s$ exist entirely in conformation 4 with $\mathrm{H}^{4}$ in the correct position to replace the leaving nitrogen at $\mathrm{C} 5$, one should expect high yields of alkenes from these compounds. However, when decomposed both in polar and nonpolar solvents, $3 r$ and $3 s$ gave cyclopropanes as the only products. An explanation for this inconsistency with earlier assumptions may be found in the serious compression of the torsion angle between the large substituents at $\mathrm{C} 4$ and $\mathrm{C} 5$ in the transition state leading to the alkene. The hypothetically formed alkene will have a neopentyl and a tert-butyl group on the same vinylic carbon atom, and if the transition state has some product-like character, serious steric hindrance is to be expected (8).

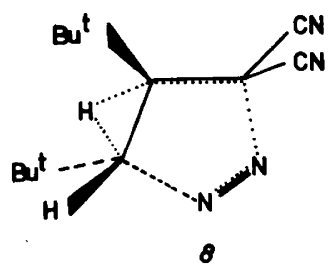

\section{EXPERIMENTAL}

General. Melting points (uncorrected) were determined on a micro hot-stage. IR spectra were recorded on a Perkin-Elmer 457 Grating Infrared Spectrophotometer, ${ }^{1} \mathrm{H}$ NMR spectra on a Varian A60A or Varian HA 100 15D spectrometer operating at $98 \mathrm{MHz},{ }^{13} \mathrm{C}$ NMR spectra on a JEOL FX-60 FT NMR spectrometer and mass spectra on an AEI MS 902 instrument. Elemental analyses were performed by I. Beetz, West Germany.

Diazoalkanes. Diazomethane, ${ }^{14}$ diazoethane, ${ }^{15}$ phenyldiazomethane ${ }^{16}$ and 1-diazo-2,2-dimethylpropane ${ }^{17}$ were prepared according to procedures described in the literature. Instead of the usual ethereal solutions, diazoalkanes in $\mathrm{CDCl}_{3}, \mathrm{CHF}_{3}, \mathrm{CHCl}_{2} \mathrm{~F}$ and $\mathrm{CCl}_{2} \mathrm{~F}_{2}$ were prepared in order to study their addition to alkenes in ${ }^{1} \mathrm{H}$ NMR tubes.

Alkenes. Alkylidenemalonate $1 e^{18}$ and alkylidenemalononitrile $1 a^{19}$ were prepared according to literature procedures. $1 b$ was synthesized by the Knoevenagel condensation between 2,2dimethylpropanal and malononitrile with Amberlite IR-45 as catalyst. ${ }^{20}$

2,4-Dimethyl-2-pentenoic nitrile $(\mathrm{E}+\mathrm{Z})$. Diethyl 1-cyano-ethanephosphonate was prepared in $0.1 \mathrm{~mol}$ scale, ${ }^{21}$ and this "one-pot olefin synthe-

Table 2. Decomposition of 1-pyrazoline-3,3-dinitriles $3\left(\mathrm{R}^{3}=\mathrm{X}=\mathrm{CN}\right)$ to give cyclopropanes 6 and alkenes $7 .^{a}$

\begin{tabular}{lllcrc}
\hline Compound & \multicolumn{2}{l}{ Solvent: ether } & \multicolumn{2}{c}{ Solvent: methanol } & Ref. \\
& 6 & 7 & 6 & 7 & \\
\hline $3 a$ & 27 & 73 & 84 & 16 & $b$ \\
$3 f$ & 9 & 91 & 100 & 0 & 1 \\
$3 g$ & 100 & 0 & 100 & 0 & 2 \\
$3 h$ & - & - & - & 83 & 10 \\
$3 r$ & 100 & 0 & 100 & 0 & $b$ \\
$3 s$ & 100 & 0 & & 0 & $b$ \\
\hline
\end{tabular}

${ }^{a}$ Yield in per cent. ${ }^{b}$ This paper. 
sis" was completed by addition of $0.1 \mathrm{~mol}$ 2-methylpropanal in THF at $-40^{\circ} \mathrm{C}$. After $1 \mathrm{~h}$ at ambient temperature, the reaction mixture was quenched with aq. ammonium chloride $(150 \mathrm{ml}$, $20 \%)$ and extracted with ether $(400 \mathrm{ml})$. After drying and evaporation, ${ }^{1} \mathrm{H}$ NMR of the residue indicated approx. 1:1 mixtures of the isomeric alkenes. Separated by fractional distillation. Isomer A: $2.9 \mathrm{~g}$, b.p.14: $39-41{ }^{\circ} \mathrm{C} .{ }^{1} \mathrm{H}$ NMR $\left(\mathrm{CCl}_{4}\right): \quad \delta 1.04(6 \mathrm{H}, \mathrm{d}, \quad J=7.0 \mathrm{~Hz}), \quad 1.8-1.9$ (3H,m), 2.5-2.9 (1H,m), $5.83(1 \mathrm{H}, 2 \mathrm{~m}, J=10.0$ $\mathrm{Hz}$. Isomer B: $3.7 \mathrm{~g}$, b.p. $14: 48-50{ }^{\circ} \mathrm{C} .{ }^{1} \mathrm{H}$ NMR $\left(\mathrm{CCl}_{4}\right): \quad \delta \quad 1.03 \quad(6 \mathrm{H}, \mathrm{d}, J=7.0 \quad \mathrm{~Hz}), \quad 1.85$ $(1 \mathrm{H}, \mathrm{d}, J=1.0 \mathrm{~Hz}), 2.4-2.8(1 \mathrm{H}, \mathrm{m}), 6.05(1 \mathrm{H}, 2 \mathrm{~d}$, $\left.J_{1}=10.0 \mathrm{~Hz}, J_{2}=1.0 \mathrm{~Hz}\right) . A+B$ : Overall yield: 6.6 g (61 \%). Anal. $\mathrm{C}_{7} \mathrm{H}_{11} \mathrm{~N}$ : C,H. IR (film): 2240 and $1650 \mathrm{~cm}^{-1}$.

4-Bromo-2,4-dimethyl-2-(Z)-pentenoic nitrile (1c). 2,4-Dimethyl-2-pentenoic nitrile $(1: 1$, $E+Z)(3.7 \mathrm{~g}, 0.03 \mathrm{~mol})$, was dissolved in tetrachloromethane $(75 \mathrm{ml})$, added NBS (6.04 g, 0.03 $\mathrm{mol}$ ) and dibenzoyl peroxide (50 $\mathrm{mg}$ ) and refluxed for $1 \mathrm{~h}$. After cooling, succinimide was filtered off and the product distilled. B.p.0.3: $56-59^{\circ} \mathrm{C}$. $4.2 \mathrm{~g}(66 \%)$. Anal. $\mathrm{C}_{7} \mathrm{H}_{10} \mathrm{BrN}$ : C,H. ${ }^{1} \mathrm{H}$ NMR $\left(\mathrm{CCl}_{4}\right): \delta 1.97(3 \mathrm{H}, \mathrm{d} J=1.0 \mathrm{~Hz}), 2.07$ $(6 \mathrm{H}, \mathrm{s}), 6.33(1 \mathrm{H}, \mathrm{q}, J=1.0 \mathrm{~Hz})$. IR (film): 2250 , $1650 \mathrm{~cm}^{-1}$. MS: $\mathrm{m} / \mathrm{e} 188+186\left(\mathrm{M}^{+}, 30 \%\right), 107$ $\left(\mathrm{M}^{+}-\mathrm{Br}, 100 \%\right)$.

2-tert-Butyl-4-methyl-2-(Z)-pentenoic nitrile. 2Methyl-propyltriphenylphosphonium bromide $(28.5 \mathrm{~g}, 0.07 \mathrm{~mol})$ was slurried in benzene $(360$ $\mathrm{ml}$ ) under nonaqueous conditions and inert atmosphere. A $15 \%$ solution of butyllithium in hexane $(46 \mathrm{ml}, 0.07 \mathrm{~mol})$ was added at $0{ }^{\circ} \mathrm{C}$. To the reddish solution of the phosphonium ylide 3,3-dimethyl-2-oxo-butyronitrile ${ }^{22}(8.0 \mathrm{~g}, 0.07$ mol) in benzene $(70 \mathrm{ml})$ was added over a period of $30 \mathrm{~min}$. The mixture was stirred $1 \mathrm{~h}$ at ambient temperature, refluxed for $5 \mathrm{~h}$ and worked up in the usual manner. Traces of triphenylphosphine oxide were removed by dissolving in pentane and eluting through a short column of alumina. After fractional distillation $2.6 \mathrm{~g}(24 \%)$ of acceptable purity (GLC>85\%) was obtained. B.p.12: 65$68{ }^{\circ} \mathrm{C}$. ${ }^{1} \mathrm{H}$ NMR $\left(\mathrm{CCl}_{4}\right): \delta 1.05(6 \mathrm{H}, \mathrm{d}, J=10.0$ $\mathrm{Hz}), 1.13(9 \mathrm{H}, \mathrm{s}), 2.6-3.0(1 \mathrm{H}, \mathrm{m}), 5.81(1 \mathrm{H}, \mathrm{d}$, $J=10.0 \mathrm{~Hz}$ ).

4-Bromo-2-tert-butyl-4-methyl-2-(Z)-pentenoic nitrile (1d). The nonbrominated alkene from above (2.1 g, $0.014 \mathrm{~mol})$ was dissolved in tetrachloromethane $(25 \mathrm{ml})$, NBS $(2.47 \mathrm{~g}, 0.014$ $\mathrm{mol}$ ) and dibenzoyl peroxide $(25 \mathrm{mg})$ was added. After $1 \mathrm{~h}$ reflux, ${ }^{\mathrm{l}} \mathrm{H}$ NMR showed complete bromination. Yield $1.9 \mathrm{~g}(59 \%)$, b.p.0.5: 56$58{ }^{\circ} \mathrm{C}$. Anal. $\mathrm{C}_{10} \mathrm{H}_{16} \mathrm{BrN}$ : C,H. ${ }^{1} \mathrm{H}$ NMR $\left(\mathrm{CDCl}_{3}\right): \delta 1.20(9 \mathrm{H}, \mathrm{s}), 2.07(6 \mathrm{H}, \mathrm{s}), 6.30(1 \mathrm{H}, \mathrm{s})$. IR (film): $2245,1650 \mathrm{~cm}^{-1}$. MS: m/e 231-229
$\left(\mathrm{M}^{+}, 14 \%\right) 150\left(\mathrm{M}^{+}-\mathrm{Br}, 100 \%\right)$.

c-4-(1-Bromo-1-methylethyl)-3,t-5-dimethyl-

4,5-dihydro-3H-pyrazole-3-carbonitrile (3o). An ether solution of $1 c(1.0 \mathrm{~g}, 5.3 \mathrm{mmol})$ and diazoethane (1 $\mathrm{g}, 18 \mathrm{mmol}$ ) was left in the dark at $5^{\circ} \mathrm{C}$ for $9 \mathrm{~d}$. After evaporation the product was

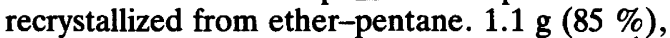
m.p. $82-85^{\circ} \mathrm{C}$ (dec). Anal. $\mathrm{C}_{9} \mathrm{H}_{14} \mathrm{BrN}$ : C,H. ${ }^{1} \mathrm{H}$ NMR $\left(\mathrm{CDCl}_{3}\right): \delta 1.59(3 \mathrm{H}, \mathrm{d}, J=7.3 \mathrm{~Hz}), 1.80$ $(3 \mathrm{H}, \mathrm{s}), 1.90(3 \mathrm{H}, \mathrm{s}), 1.95(3 \mathrm{H}, \mathrm{s}), 3.0(1 \mathrm{H}, \mathrm{m})$, $5.11(1 \mathrm{H}, 2 \mathrm{q}, J=7.3 \mathrm{~Hz}$, sep. of quartets: $5.4 \mathrm{~Hz})$ ${ }^{13} \mathrm{C}$ NMR $\left(\mathrm{CDCl}_{3}\right): \delta$ 20.5-29.3-31.2-33.3 (4×Me), $62.2(\mathrm{C} 4), 63.0\left(\mathrm{CBrMe}_{2}\right) 85.1$ (C3), 91.0 (C5), $117.3(\mathrm{C} \equiv \mathrm{N})$. IR (KBr): 2250, 1555 $\mathrm{cm}^{-1}$.

c-4-(1-Bromo-1-methylethyl)-3-tert-butyl-4,5dihydro-3H-pyrazole-3-carbonitrile (3q). An ether solution of $1 d(0.5 \mathrm{~g}, 2.2 \mathrm{mmol})$ and diazomethane $(0.42 \mathrm{~g}, 10 \mathrm{mmol})$ was left in the dark at room temperature for $15 \mathrm{~d} .{ }^{1} \mathrm{H}$ NMR of the reaction mixture showed complete reaction. Yield $0.54 \mathrm{~g}(91 \%)$. M.p. $81-83^{\circ} \mathrm{C}$ (dec.chloroform-pentane). Anal. $\mathrm{C}_{11} \mathrm{H}_{18} \mathrm{BrN}$ : C,H,N. ${ }^{1} \mathrm{H} \mathrm{NMR}\left(\mathrm{CDCl}_{3}\right): \delta 1.1(9 \mathrm{H}, \mathrm{s}), 1.78(3 \mathrm{H}, \mathrm{s}), 1.98$ (3H,s), ABX-system: $v_{\mathrm{X}}=2.70, \quad v_{\mathrm{B}}=4.76$, $v_{\mathrm{A}}=5.28, J_{\mathrm{AB}}=19.4 \mathrm{~Hz}, J_{\mathrm{AX}}=4.1 \mathrm{~Hz}, J_{\mathrm{BX}}=9.3$ Hz. IR (KBr): $2250,1555 \mathrm{~cm}^{-1}$.

The reaction between $2 \mathrm{~b}$ and $1 \mathrm{a}$. To a solution of $2 b$ in $\mathrm{CCl}_{3} \mathrm{~F}$ cooled to $-60^{\circ} \mathrm{C}$ was added $1 a$ dissolved in acetone- $d_{6}$ until the yellow color of diazoalkane disappeared (approx. $1 \mathrm{~mol} \mathrm{eqv}$. required). The ${ }^{1} \mathrm{H}$ NMR spectrum of the solution was recorded immediately at $-60^{\circ} \mathrm{C}$ and showed the formation of $3 m: \delta 1.74(3 \mathrm{H}, \mathrm{d}, J=6.7 \mathrm{~Hz})$. $2.00(3 \mathrm{H}, \mathrm{s}), 2.16(3 \mathrm{H}, \mathrm{s}), 3.16(1 \mathrm{H}, \mathrm{d}, J=6.7 \mathrm{~Hz})$. $5.43(1 \mathrm{H}, 2 \mathrm{q}, J=6.7 \mathrm{~Hz}$, sep. of quartets. $6.7 \mathrm{~Hz})$. When heated, nitrogen was evolved, leaving unidentified material behind.

The reaction between $2 \mathrm{a}$ and $1 \mathrm{~b} .1 \mathrm{~b}(0.5 \mathrm{~g}, 3.7$ mmol) was dissolved in min. amounts of ether, cooled to $-78^{\circ} \mathrm{C}$, and a $2 \mathrm{M}$ ethereal solution of $2 a(1.9 \mathrm{ml}, 3.8 \mathrm{mmol})$ was added. After $1 \mathrm{~h}$ pentane was added and the precipitated white solid was quickly filtered off and stored at $-78^{\circ} \mathrm{C}$. The crystals were dissolved in cold $\mathrm{CHCl}_{2} \mathrm{~F}$, and ${ }^{1} \mathrm{H}$ NMR spectra run at $-50{ }^{\circ} \mathrm{C}$ and $-130{ }^{\circ} \mathrm{C}$, thus identifying the structure $3 a ;-50^{\circ} \mathrm{C}: \delta 1.20$ (9H,s), ABX-system: $v_{\mathrm{X}}=2.51, \quad v_{\mathrm{A}}=5.18$, $v_{\mathrm{B}}=4.67, J_{\mathrm{AB}}=18.2 \mathrm{~Hz}, J_{\mathrm{AX}}=8.3 \mathrm{~Hz}, J_{\mathrm{BX}}=10.7$ Hz. $-1300^{\circ} \mathrm{C}: \delta 1.21 \quad(9 \mathrm{H}, \mathrm{s}), \quad \mathrm{ABX}$-system: $v_{\mathrm{X}}=2.53, v_{\mathrm{A}}=5.41, v_{\mathrm{B}}=4.47, J_{\mathrm{AB}}=18.0 \mathrm{~Hz}$, $J_{\mathrm{AX}}=7.8 \mathrm{~Hz}, J_{\mathrm{BX}}=11.5 \mathrm{~Hz}$.

Decomposition of $3 \mathrm{a} .100 \mathrm{mg} 3 a$ was dissolved in methanol at room temperature under vigorous evolution of nitrogen. The product was shown by ${ }^{1} \mathrm{H}$ NMR to consist of an 84:16 mixture of 2-tert-butyl-1,1-cyclopropanedicarbonitrile ${ }^{23}$ and 1,2,2-trimethylpropylidenemalononitrile. ${ }^{24}$ In 
ethereal solution the evolution of nitrogen was slower, giving the same products in 27:73 ratio.

The reaction between $2 \mathrm{~d}$ and $1 \mathrm{a}$. To a solution of $1 a(1.0 \mathrm{~g}, 5.0 \mathrm{mmol})$ in ether $(5 \mathrm{ml}) 2 d(0.5 \mathrm{~g}$, $5.1 \mathrm{mmol})$ in ether $(2.5 \mathrm{ml})$ was added at $-78^{\circ} \mathrm{C}$. The immediate disappearance of the yellow color of diazoalkane without any gas evolution indicated the formation of a pyrazoline, which after some time precipitated from the solution. After filtration, the crystals were quickly dissolved in cold $\mathrm{CCl}_{3} \mathrm{~F}$ and ${ }^{1} \mathrm{H}$ NMR spectrum run at $-60^{\circ} \mathrm{C}$ identified the crystals as $3 s: \delta 1.10(9 \mathrm{H}, \mathrm{s}), 1.90$ $(3 \mathrm{H}, \mathrm{s}), 2.15(3 \mathrm{H}, \mathrm{s}), 3.22(1 \mathrm{H}, \mathrm{d}, J=2.8 \mathrm{~Hz}), 5.57$ $(1 \mathrm{H}, \mathrm{d}, J=2.8 \mathrm{~Hz})$.

Decomposition of $3 \mathrm{~s} .3 \mathrm{~s}$ decomposed readily at room temperature, either neat, in methanol or in ether to give a single product which was identified as trans-2-(1-bromo-1-methylethyl)-3-tertbutyl-1,1-cyclopropanedicarbonitrile. M.p. 110 $111^{\circ} \mathrm{C}$ (ether-pentane). Anal. $\mathrm{C}_{12} \mathrm{H}_{17} \mathrm{BrN}_{2}$ : $\mathrm{C}, \mathrm{H}, \mathrm{N}$. ${ }^{\mathrm{H}} \mathrm{NMR}\left(\mathrm{CDCl}_{3}\right): \delta 1.32(9 \mathrm{H}, \mathrm{s}), 1.88$ $(3 \mathrm{H}, \mathrm{s}), 1.97(3 \mathrm{H}, \mathrm{s}), 2.07(1 \mathrm{H}, \mathrm{d}, J=10.0 \mathrm{~Hz})$, $2.47(1 \mathrm{H}, \mathrm{d}, J=10.0 \mathrm{~Hz})$. MS: $\mathrm{m} / \mathrm{e} 189\left(\mathrm{M}^{+}-\mathrm{Br}\right.$, $2 \%), 57\left(\mathrm{C}_{4} \mathrm{H}_{9}{ }^{+}, 100 \%\right)$.

The reaction between $2 \mathrm{~d}$ and $1 \mathrm{~b}$. To a solution of $1 b$ in acetone- $d_{6}$ at $-78^{\circ} \mathrm{C}$ was added an approx. equimolar amount of $2 d$ in $\mathrm{CCl}_{3} \mathrm{~F}$ under immediate disappearance of the color of the diazoalkane. ${ }^{1} \mathrm{H}$ NMR spectra were run at $-30^{\circ} \mathrm{C},-60^{\circ} \mathrm{C}$ and $-90^{\circ} \mathrm{C}$, showing the formation of $3 r$ :

$-30{ }^{\circ} \mathrm{C}: \delta 1.06(18 \mathrm{H}$, broad s), $2.74(1 \mathrm{H}, \mathrm{d}$, $J=3.2 \mathrm{~Hz}), 5.48(1 \mathrm{H}, \mathrm{d}, J=3.2 \mathrm{~Hz})$.

$-60^{\circ} \mathrm{C}: \delta 1.02(3 \mathrm{H}, \mathrm{s}), 1.07(12 \mathrm{H}$, broad s), 1.17 $(3 \mathrm{H}, \mathrm{s}) 2.83(1 \mathrm{H}, \mathrm{d}, J=3.1 \mathrm{~Hz}), 5.54(1 \mathrm{H}, \mathrm{d}, J=3.1$ Hz).

$-90{ }^{\circ} \mathrm{C}: \delta 0.86(3 \mathrm{H}, \mathrm{s}), 1.09(9 \mathrm{H}$, broad s), 1.17 $(3 \mathrm{H}, \mathrm{s}) 1.37(3 \mathrm{H}, \mathrm{s}), 2.91(1 \mathrm{H}, \mathrm{d}, J=2.1 \mathrm{~Hz}), 5.62$ $(1 \mathrm{H}, \mathrm{d}, J=2.1$. Hz).

Decomposition of $3 \mathrm{r}$. The $\mathrm{CCl}_{3} \mathrm{~F}$-acetone- $d_{6}$ solution of $3 r$ from the ${ }^{1} \mathrm{H}$ NMR experiment above was allowed to warm up to room temperature, resulting in evolution of nitrogen. On the basis of the similarity of the ${ }^{1} \mathrm{H}$ NMR spectrum to that of 2-tert-butyl-1,1-cyclopropanedicarbonitrile,$^{23}$ the product was assumed to be nearly pure trans 2,3-di-tert-butyl-1,1-cyclopropanedicarbonitrile. ${ }^{1} \mathrm{H}$ NMR $\left(\mathrm{CCl}_{3} \mathrm{~F}\right.$-acetone- $\left.d_{6}\right): \delta$ $1.13(18 \mathrm{H}, \mathrm{s}), 2.00(2 \mathrm{H}, \mathrm{s})$.

The reaction between $2 \mathrm{~b}$ and $1 \mathrm{e}$. To a solution of $1 e(2.0 \mathrm{~g}, 7.5 \mathrm{mmol})$ in ether was added $2 b(0.5$ $\mathrm{g}, 8.9 \mathrm{mmol}$ ) and the mixture was left overnight at room temperature in the dark. The product (3j) was precipitated from the solution by adding pentane. Yield: $1.7 \mathrm{~g} \quad(70 \%)$. Anal. $\mathrm{C}_{11} \mathrm{H}_{17} \mathrm{BrN}_{2} \mathrm{O}_{4}$ : C,H. M.p. $88-90^{\circ} \mathrm{C}$ (ether-pentane). ${ }^{1} \mathrm{H}$ NMR $\left(\mathrm{CDCl}_{3}\right): \delta 1.68(3 \mathrm{H}, \mathrm{d}, J=7.1$
$\mathrm{Hz}), 1.88(6 \mathrm{H}, \mathrm{s}), 2.67(1 \mathrm{H}, \mathrm{d}, J=7.8 \mathrm{~Hz}), 3.75$ $(3 \mathrm{H}, \mathrm{s}), 3.90(3 \mathrm{H}, \mathrm{s}), 4.85(1 \mathrm{H}, 2 \mathrm{q}, J=7.1 \mathrm{~Hz}$, sep. of quartets: $7.8 \mathrm{~Hz}$ ).

\section{REFERENCES}

1. Kolsaker, P., Storesund, H.J., Gulbrandsen, T. and Wøien, G. Acta Chem. Scand. B 37 (1983) 187.

2. Gulbransen, T. and Kolsaker, P. Acta Chem. Scand. B 37 (1983) 197.

3. Gulbrandsen, T. and Kolsaker, P. Acta Chem. Scand. B 34 (1980) 305.

4. Mackenzie, K. In Patai, S., Ed., The Chemistry of the Hydrazo, Azo and Azoxy Groups, Wiley, London 1975, p. 329.

5. Gulbrandsen, T., Rømming, C. and Kolsaker, P. Acta Chem. Scand. B. 37 (1983) 203.

6. a. McGreer, D.E. and McKinley, J.W. Can. J. Chem. 49 (1971) 105; b. Hamelin, J. and Carrié, R. Bull. Soc. Chim. Fr. (1972) 2054; c. McGreer, D.E., Chiu, N.W.K., Vinje, M.G. and Wong, K.C.K. Can. J. Chem. 43 (1965) 1407.

7. Crawford, R.J. and Ali, L.H. J. Am. Chem. Soc. 89 (1967) 3908.

8. Danion-Bougot, R. and Carrié, R. Org. Magn. Reson. 5 (1973) 453.

9. Kirsch, H. and Polansky, O..E. Tetrahedron Lett. (1969) 805.

10. Tortschanoff, K., Kirsch, H. and Polansky, O.E. Justus Liebigs Ann. Chem. (1975) 449.

11. House, H. Modern Synthetic Reactions, 2nd Ed., Benjamin, Menlo Park 1972, p. 682.

12. $C f$. the ${ }^{1} \mathrm{H}$ NMR spectra of $1 a^{19}$ and $1 e^{18}$ and their nonbrominated analogues.

13. Emsley, J.W., Feeney, J. and Sutcliffe, L. H. High Resolution NMR, Pergamon, Oxford 1966, Vol. 2 , p. 678.

14. Org. Synth. Coll. Vol. 2 (1943) 165.

15. Org. Synth. Coll. Vol. 2 (1943) 278.

16. Closs, G.L. and Moss, R.A. J. Am. Chem. Soc. 86 (1964) 4042.

17. Kaufman, G.M., Smith, J.A., Vanderstouw, G.G. and Shechter, H. J. Am. Chem. Soc. 87 (1965) 935.

18. Kolsaker, P. and Storesund, H.J. Chem. Commun. (1972) 375.

19. Storesund, H.J. and Kolsaker, P. Tetrahedron 30 (1974) 3153.

20. Cope, A.C. J. Am. Chem. Soc. 63 (1941) 3455.

21. Comins, D.L., Jacobine, A.F., Marshall, J.L. and Turnbull, M.M. Synthesis (1978) 309. 
22. Clement, B.A. and Soulen, R.L. J. Org. Chem. 39 (1974) 97.

23. Treder, M.H., Kratzin, H., Lübbecke, H., Yang, C.Y. and Boldt, P. J. Chem. Res. S (1977) 165.

24. Cabaret, D., Capillon, J. and Guette, J.P. J. Organomet. Chem. 113 (1976) 215.

Received June 14, 1982. 